\title{
A Study on the US Trade Policy towards China
}

\author{
Xin $\mathrm{Kai}^{1}$ \& Jiexin $\mathrm{Liao}^{2}$ \\ ${ }^{1}$ School of Economics, Central University of Finance and Economics, Beijing, China \\ ${ }^{2}$ School of Finance, Central University of Finance and Economics, Beijing, China \\ Correspondence: Xin Kai, School of Economics, Central University of Finance and Economics, Beijing, \\ China,102206. Tel: 86-136-8116-9036. E-mail: kaixin@email.cufe.edu.cn
}

Received: April 19, 2021

Accepted: May 24, 2021

Online Published: June 5, 2021

doi:10.5539/ijef.v13n7p21

URL: https://doi.org/10.5539/ijef.v13n7p21

\begin{abstract}
The Sino-US trade relationship has become one of the most important bilateral trade relationships in the world, however there are emerging more and more conflicts between them which may have negative impact on global trade. This paper reviews the US trade policy towards China and analyzes the reasons why these policies are changing over time. Based on related economic and political theories, this paper points out that there are political reasons, economic reasons and external factors that account for the changing of the US trade policies towards China. Furthermore, among these factors, the Sino-US political relationship laid the foundation of the bilateral trade relationship especially at an early stage, and the economic factor explains most of the bilateral trade after 2000. Meanwhile, the fluctuation of the bilateral trade could largely be explained by the struggle of the balance of the US domestic interest groups, and the balance of some external factors like international treaties.
\end{abstract}

Keywords: Sino-US trade, trade policy, trade theory, national strategy, interest group, political cycle

\section{Introduction}

The trade between China and the US has last for centuries since the arrival of the US merchant ship "THE EMPRESS OF CHINA" at the Huangpu Port of China in August 1748. Today, the two economies have become the second largest trade partner of each other and the total trade value between them has reached $\$ 586.7$ billion in 2020. However, since the 2008 global financial crisis, the US economics has been undergoing a lowest period after the World War II. To walk out the shadow of the economic downturn, the US government is generally implementing trade protectionism rather than free trade policies on Chinese goods. After Donald Trump came to power in 2017, in spite of the international agreements such as WTO, the Trump administration launched a trade dispute with China and imposed 5-25\% tariff on Chinese goods worth more than $\$ 200$ billion. These actions might help to bring the US certain benefits but will have a negative effect on the bilateral trade and the global economy, especially in the global economic downturn.

Thus, analyzing the causes of the changing of US trade policy towards China and studying the theories and mechanism behind the phenomenon have a practical significance. In the literature, there has been a lot of discussion about trade theory, but since Trump came to power, a series of new trade disputes was launched. The reasons behind these phenomena have not been fully studied. Based on the literature, this paper reviews the US trade policy towards China and analyzes the reasons why the policies are changing over time. We integrate these changes into a unified framework, so as to point out the continuity and particularity of these changes.

The rest of this article will be divided into four parts: Firstly, the paper will give a review of the US trade policy towards China since 1949. Secondly, some related trade and political theories will be introduced. Thirdly, the paper lays out the reasons why the US government changes the trade policies toward China according to these theories. The last part is conclusions.

\section{A Brief Review of Sino-US Trade History}

The Sino-US trade relationship could be generally divided into four periods since 1949, the founding of the People Republic of China.

\subsection{1970: The Stage of Severely Confronting}

At the beginning of the new China, the two countries did keep a good trade relationship: the total value of the trade between them reached up to $\$ 0.2$ billion in 1949 and $\$ 0.24$ billion in 1950 . However, as the new China is a 
communism country while the U.S. represents the capitalism country, and with the explosion of the Korean War, the U.S. government issued several sanctions policies including embargo and listed the new China as an enemy. Then the bilateral trade plunged to \$800 million in 1951, \$53 thousand in 1952 and only \$2 thousand in 1953 . From 1953 to 1970, the trade was completely blocked.

\subsection{1988: The Stage of Recovery and Comprehensive Contact}

At the beginning of the 1970s, the Chairman Mao administration gradually abandoned the idea that the US was his enemy and the Sino-US relationship generally recovered. As president Nixon - the first US president visited China in 1972 and with the publish of the "Shanghai Communique", the Sino-US political and economic relationship was taken into a new era and the 20 -year-embaro was finally ended. The total trade value increased sharply to $\$ 490$ million in 1971, $\$ 0.1$ billion in 1972 and surged to as much as $\$ 1$ billion. However, the figure dropped to $\$ 0.5$ billion due to the Taiwan crisis in 1975 .

Generally speaking, this period cast a bright future on Sino-US trade relationship. In 1979, the China and the US government formally established diplomatic relationship, signed the "Sino-US Trade Relationship Treaty" and given each other the famous "MFN", namely the most favored nation treatment. The trade value rose from $\$ 2.45$ billion in 1979 to $\$ 10$ billion in 1988 .

\subsection{2000: The Complicated Stage-Combination of Repression and Cooperation}

1989 is a special year for Sino-US trade relationship because of a political event. The US government hooked the trade policy towards China with the issue of human right. The US government suddenly issued weapon embargo towards China, suspended several commercial cooperation and communication of the high level of two governments.

However, the rapid development of China economy and the cheap goods made in China were really a temptation to the US government. Also thanks to the long eye-sight of the two leaders of that time-chairman Deng Xiaoping of China and US president senior Bush, the two administration put more emphasis on the common interest of the two economies. Though Clinton imposed contact strategy featured repression in his first term, he gradually adjusted his strategy and upgraded it to comprehensive contact and cooperation in his second term as the recognition of China's ever growing economic power. Meanwhile, the trade amounted from $\$ 12.3$ billion in 1989 to $\$ 74.5$ billion in 2000 .

\subsection{Till Now: The Stage Filled with Discriminatory Policy}

China finally joined the WTO after 15 years of tough negotiation in 2001, however the US suffered a terrible terrorist attack also in 2001. Both the events tied China and the US more tightly in political cooperation and economic cooperation as well. The junior Bush administration and Obama administration establish a healthy trade relationship with China government (Zhang, 2009).

On the other hand, because of the junior Bush administration's "Prevention and Containment" policy and Obama administration's "Competitor Relationship" policy towards China, the US government initiated several anti-subsidy and anti-dumping investigations and even posed penalty on Chinese goods (Tu, 2007). Although the total value of the bilateral trade added up from $\$ 80$ billion in 2001 to $\$ 520$ billion in 2013 and the two countries have business in many areas, the US still posed some discriminatory trade policy towards China. These measures became particularly severe after Trump administration came into power in 2017 as his election slogan was "America First".

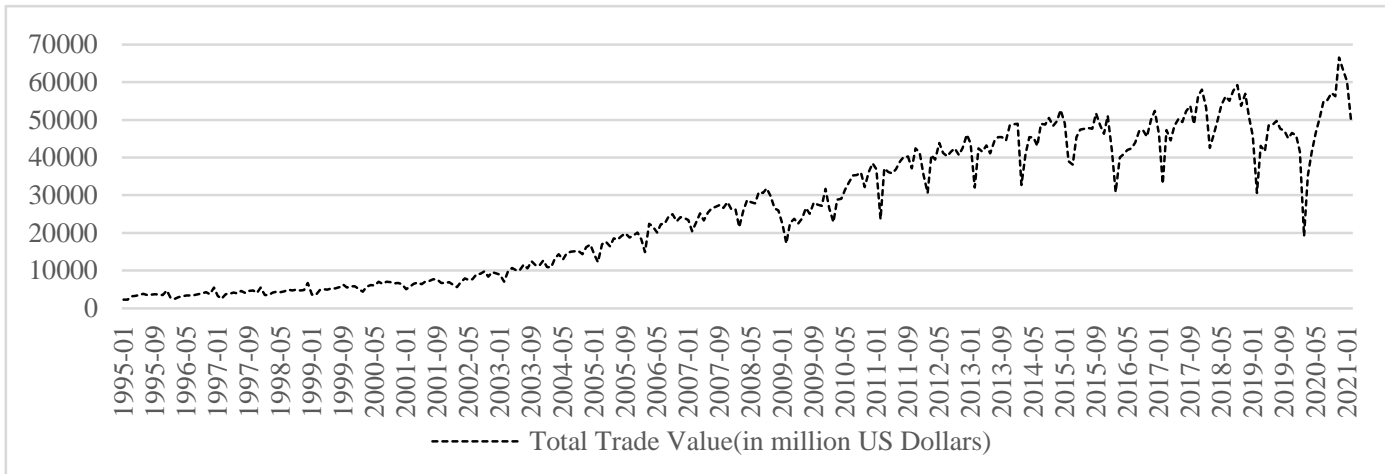

Figure 1. Total value of Sino-US goods trade from Jan 1995 to Feb 2021

Source: CEIC Statistics Database. 


\section{Theories Background}

Some related economic and political theories should be introduced here before we continue to explain the reasons behinds the changing of US trade policy towards China and help us to understand these reasons better.

\subsection{Theory of Comparative Advantage}

In an economic model, an agent has a comparative advantage over another in producing a particular good if he can produce that good at a lower relative opportunity cost. David Ricardo developed the theory in 1817 to explain why countries engage in international trade even when one country's workers are more efficient at producing every single good than workers in other countries. He demonstrated that if two countries capable of producing two commodities engage in a free market, then each country will increase its overall consumption and wealthy by exporting the good for which it has a comparative advantage while importing the good the encounter country has a comparative advantage.

\subsection{Theory of Free Trade}

Trade policies are generally divided into two types: free trade and protective trade. Free trade is the core of the classical economics theory. Adam Smith put forward the famous theory of "invisible hand" that the price signal would naturally adjust the demand and supply, and the resource and factors would be distributed fairly and effectively because every participator is self-interested. The theory of free trade emphasizes that the government should not impose any restrictions on the import and export. Each participator will naturally gain its interest when engaged in the international market.

\subsection{Theory of Fair Trade}

Fair trade policy is one of the popular protective trade policies, which a government takes to protect its own domestic market and enhance its products' competitiveness in foreign markets. The theory of fair trade generally holds the idea that the exports must comply with products standard of the destination country such as whether the production process of these exports is environmental-friendly, or satisfies the labor standard. Though the principle of fair trade is to help export country to upgrade industrial structure, some of the standards or restrictions imposed on the export are really hard to be satisfied.

\subsection{Interest Groups}

Interest group is mainly a political concept and represents a group shared a common sense of a particular interest and then influence the society and government through some approach such as the interest group is the main and important donors of the president candidates (Wang, Li, Xie, \& Hou, 2013).

\section{Why the US Government Change Trade Policies towards China?}

From each stage of the Sino-US trade relationships presented in the second part, and according to the trade theories introduced above, we may find that there are mainly three reasons why the US changes its trade policies towards China, including political, economic and external aspects.

\subsection{Political Reasons}

In this part, we will analyze the political factors within the trade policy's decision-making mechanism.

\subsubsection{The Overall US National Strategy}

From the perspective of politics, the US trade policy towards China is one part of its overall national foreign strategy.

In the period of 1949 1970, as the new China was a communism country and an alliance with the Soviet Union, and the China government sent army to aid the north Korean to fight against the US, the US government must spare no efforts to contain the new China. Thus the US trade policy towards China of this period is severely confronting and completely containing.

From 1971 to 1988 , the idea of free market and free trade dominated the economic policy in the western countries and with the establishment of the diplomatic relations of the two countries in 1978 the Sino-US trade relationship began to recover. In the following decade, as Clinton came into power and the US was experiencing its fastest economic development after the World War II, the overall US national policy is comprehensive contact and engagement with China, and thus the US could gain its status as the world leader in politics and economics, so we see a surge of trade in that period.

Since 2001, as the anti-terrorism became the basic mission of the U.S. government, the US must draw every potential country to its side to combat the terrorism. Also as China became a member of WTO in 2000, this 
period saw a rapid development of the Sino-US trade relationship. However, when Obama came into force in 2008, the US was in the shadow of global economic depression. To get rid of the crisis and re-gain its world leader power, the U.S. government took the conditional free trade policy towards china, like fair trade policy to protect its domestic market. Similarly, Trump administration took more protectionist trade policies (Gong, 2018).

In conclusion, the US overall national foreign strategy and Sino-US political relationship laid the foundation of the changing of US trade policy towards China at the earlier period of the bilateral trade.

\subsubsection{The Influence of the US Domestic Interest Groups}

These domestic interest groups that may have a substantial influence on the US trade policy towards China (Wang, 2016), and it could be divided into two kinds.

One side is the US domestic industrial and commercial interest groups that represent the most important group in favor of a friendly trade relationship towards China. As the price of labor in the US domestic market is quite high, the US companies must find substitution for the domestic labor to manufacture products, particularly those low value added products. And also because of the limitation of the US domestic market, those companies must explore their business in the foreign market. Generally they are the moralists the free trade policy. China satisfied these requires mostly as China is the largest developing country and have a stable domestic political atmosphere. That's why we can see a surge in the total trade value between the two countries after the establishment of the Sino-US diplomatic relationship, especially after the reform and opening-up policy of China came into force.

While the opposite group which oppose to a kindly relationship with China may be represented by those social groups like the human rights organization, environmental protection group and labor standard group. Generally these interest groups are the symbol of fair trade. They insist that the interest gained from the international trade mustn't be at the cost of others' interest. That's the reasons why the two countries are cooperating in more and more areas while the trade conflicts are also rising surprisingly and even the US sometimes enforces severe sanctions on Chinese goods.

However, the influence of different interest groups on US trade policies has become blurred. For example, the relationship between blue collar workers and farmers represented by Trump and China has gradually deteriorated, while environmental protection organizations have closer cooperation with China.

\subsubsection{The Cycle of the US Political System}

The political system applied by the US is the combination of legislation, justice and administration. Each term of office of the administration department represented by the president is four years, while the term of office of the legislation department represented by the congress is two years, and the justice applies the lifelong tenure.

Then comes the problem. Not only the candidate's personality and statecraft attracts the voters, but the election skills also influence the situation of election to a large extent. Thus China becomes the target of public criticism. The candidates usually criticize China's labor standard, human rights, trade deficits, and environmental problem, etc. So when each president comes into power, the US usually takes a relatively tight trade policy towards China at the beginning as realization of his election promise and a relative more friendly trade policy later. The pace of the changing of trade policy towards China of the Clinton and junior Bush administration demonstrated the theory well.

\subsection{Economic Reasons}

In this part we will analyze how economic factors influencing the decision-making mechanism of the US trade policy towards China.

\subsubsection{Chinese Goods: An Irresistible Temptation}

China is the largest developing country with cheap product factors like labor and rich natural resources that attribute to China's largest population and third largest territory in the world. Meanwhile, the social and political atmosphere is relatively stable which can low the risks when doing business with China. Thus having trade with China is largely a win-win business.

Though the US has absolute advantage of product efficiency over China in almost every product because of its high-tech, China has comparative advantage in particular products, especially in traditional labor-intensive products and some capital-intensive products while the US has comparative advantage in technology-intensive products, which enables both countries to gain more profits according to the principle of comparative advantage theory (Liang, 2007). 


\subsubsection{The Interest of the US Domestic Enterprises}

As mentioned above, the US is a developed country and the prices of its product factors are relatively high. The wage paid to an American worker is much more than that of a Chinese worker. Thus hiring such "expensive" workers to produce some labor-intensive goods is a kind of "waste", and the price of a product made in US will also be much higher than the same product exported from China. Obviously the Chinese goods will "win" over the US-made goods, meanwhile more US labor could be saved for more complicated production.

What's more, some sunset industries in the developed countries may be sunrise industries in the developing countries, and the former always face with the problem of relative excess capacity in industry. So the US can transfer its excess-capacity-industries to China through the bilateral trade, and China can also benefit from this because technology is also transferred. That's why the US industrial and commercial groups usually stands by the Chinese goods when some US social groups like human rights organizations want to exert restrictions on the Chinese goods.

On the other hand, however, even the US industrial and commercial groups won't stand by the Chinese products forever, peculiarly when the US economy is undergoing a low period. The US public and some infant industries always criticize the US government's weak trade policies towards China, as the Chinese goods are too competitive to occupy most of the US domestic market shares.

\subsection{External Factors}

Besides the political and economic reasons, some external factors also influence the decision-making mechanism of the US trade policy towards China.

The external factors are mainly inferred to these international treaties the US signed or international organizations the US joined. As both the US and China are members of the WTO, the US must behave under the framework of the WTO charter in bilateral trade with China though sometimes reluctant in the economic downturn. Other FTA-free trade agreements covered the two countries have the same power to regulate the two countries trade behavior.

\section{Conclusions}

The US and China are the two largest economies in the world, and their trade relationship is important to the world economy. However, after Trump came into power in 2017, many sanctions have been launched on Chinese goods. One interesting and essential question is why the US government carried out these policies even at the cost of the development of the world economy. What's more, have these phenomenon or similar events happened in the history?

In this paper, we review the history of the US trade policy towards China and introduce some related trade theories, we find some features of the changing of the US trade policy towards China. Firstly, the Sino-US political relationship laid the foundation of the bilateral trade relationship and used to be the only dominance in the bilateral trade at the first beginning of the new China. However, with the establishment of the diplomatic relationship of the two countries and a relative peaceful atmosphere between them, the political influence gradually becomes less important. Secondly, the economic factor explains most of the bilateral trade after 2000, and meanwhile the fluctuation of the bilateral trade could largely be explained by the struggle of the power balance of the US domestic interest groups. The third feature is that the external factors like international treaties have a quite limited influence on the decision-making mechanism. Although the behavior of the US would not be out of the framework of the international treaties, the US government usually exerts discriminatory investigation or even penalties on Chinese goods with the excuses such as the principle of fair trade or domestic interests.

This study contributes to the existing literature by combing the trade theory and reality, combining the history and the current, and integrating these policy changes into a unified framework, so as we could point out the continuity and particularity of these changes. Understanding why the US government changes the trade policy towards China not only helps the two countries' administrative departments to deal with conflicts more properly, but also is a useful supplement to the existing trade theories.

\section{References}

Gong, T. (2018). Development in US trade policy towards China and outlook for China-US trade relations. China International Studies, 4, 152-168.

Liang, B. (2007). Political economy of US trade policy towards China. China and World Economy, 15(5), 50-64. https://doi.org/10.1111/j.1749-124X.2007.00088.x

Tu, X. (2007). The US trade policy towards China since China's entry into WTO. World Economy Studies, 
165(11), 30-36. https://doi.org/10.13516/j.cnki.wes.2007.11.006

Wang, X., Li, S., Xie, S., \& Hou, J.(2013). How is US trade policy towards China determined? China Economic Review, 12(27), 25-36. https://doi.org/10.1016/j.chieco.2013.07.008

Wang, Y. (2016). The US congress and the trade policy towards China: An analysis of the currency exchange rate oversight reform act of 2011 and amendment to Tariff Act of 1930. Zhejiang Social, 9, 144-151. https://doi.org/10.14167/j.zjss.2016.09.015

Zhang, J. (2009). The Obama administration's trade policy towards China and Sino-US economic and trade relations. International Forum, 11(4), 30-36. https://doi.org/10.13549/j.cnki.cn11-3959/d.2009.04.013

\section{Copyrights}

Copyright for this article is retained by the author(s), with first publication rights granted to the journal.

This is an open-access article distributed under the terms and conditions of the Creative Commons Attribution license (http://creativecommons.org/licenses/by/4.0/). 